\title{
PENINGKATAN KEMAMPUAN BERPIKIR KREATIF MATEMATIS SISWA KELAS VIII MELALUI PEMBELAJARAN MATEMATIKA REALISTIK
}

\section{IMPROVING MATHEMATIC CREATIVE THINKING ABILITY OF CLASS VIII STUDENTS THROUGH REALISTIC MATHEMATICS EDUCATION}

\author{
Rania Darus Suciati*, Dina Maulida, Tia Nur Tartilah, Ratu Sarah Fauziah \\ Iskandar \\ Universitas Muhammadiyah Tangerang, Jl. Perintis Kemerdekaan No. I / 33, Cikokol, Tangerang, telp \\ (021) 5537198 / fax (021) 55793802 \\ raniadarussuciati@gmail.com
}

\begin{abstract}
This study aims to improve the ability of junior high school students' mathematical creative thinking through Realistic Mathematics Education (RME) on the material system of two-variable linear equations. Improvement is reviewed based on the ability of students to answer questions that have been prepared based on aspects of creative thinking abilities. The research method uses a quantitative research design by providing pretest and posttest questions. The research sample involved 82 students of class VIII Madrasah Tsanawiyah Al-Kamil, consisting of one experimental class and one control class randomly selected. The research instrument uses essay questions as much as 4 items to measure mathematical creative thinking skills. Data analysis conducted in this research was in the form of normality, homogeneity, and normalized gain test. The results showed that the use of RME was considered ineffective so that the increase that occurred was very low.
\end{abstract}

Keywords: Creative Thinking, Realistic Mathematic Education

\begin{abstract}
ABSTRAK
Penelitian ini bertujuan mengetahui peningkatan kemampuan berpikir kreatif matematis siswa SMP melalui Pembelajaran Matematika Realistik (PMR) pada materi sistem persamaan linier dua variabel. Peningkatan ditinjau berdasarkan kemampuan peserta didik menjawab pertanyaan yang telah disusun berdasarkan aspek kemampuan berpikir kreatif. Metode penelitian menggunakan rancangan penelitian kuantitatif dengan memberikan soal pretest dan postest. Sample penelitian melibatkan 82 peserta didik kelas VIII Madrasah Tsanawiyah Al-Kamil, terdiri dari satu kelas eskperimen dan satu kelas control yang dipilih secara acak. Instrumen penelitian menggunakan soal berbentuk esai sebanyak 4 butir pertanyaan untuk mengukur kemampuan berpikir kreatif matematis. Analisis data yang dilakukan dalam penelitian ini berupa uji normalitas, homogenitas, dan uji normalized gain. Hasil penelitian menunjukkan bahwa penggunaan PMR dinilai kurang efektif sehingga peningkatan yang terjadi pun sangat rendah.
\end{abstract}

Kata Kunci: Berpikir Kreatif, Pembelajaran Matematika Realistik 


\section{PENDAHULUAN}

Pendidikan merupakan salah satu hal yang dapat membentuk sikap dan karakter manusia menjadi lebih baik. Bahkan dalam Undang-Undang No. 23 Tahun 2003 tertuang bahwa pendidikan adalah usaha sadar dan terencana untuk mewujudkan suasana belajar dan proses pembelajaran agar peserta didik secara aktif mengembangkan potensi dirinya untuk memiliki kekuatan spiritual keagamaan, pengendalian diri, kepribadian, kecerdasan, akhlak mulia, serta keterampilan yang diperlukan dirinya, masyarakat, bangsa dan negara.

Matematika merupakan salah satu materi pembelajaran yang mempunyai peranan penting dalam kehidupan. Adapun tujuan mempelajari matematika adalah untuk membekali peserta didik dalam mengasah kemampuan bernalar, berpikir logis, sistematis, aktif, dan kreatif. Hal ini sesuai dengan pendapat (Handoko, 2017) yang menyatakan bahwa matematika difungsikan sebagai perkembangan dalam kemampuan berpikir kreatif, logis, sistematis, dan disiplin dalam kehidupan yang kompetitif. Oleh karena itu, apabila peserta didik telah mencapai tujuan tersebut maka akan berdampak pula pada taraf hidup sosialnya. Salah satu contoh tujuan matematika yang memiliki peranan penting dalam kehidupan bermasyarakat adalah kemampuan berpikir kreatif. Dengan berpikir kreatif, seseorang akan mampu menghadapi berbagai permasalahan yang ada di lingkungannya. Seperti yang dipaparkan oleh (Wijaya, 2012) bahwa untuk menyelesaikan berbagai persoalan dalam kehidupan masyarakat maka sebagian keterampilan yang harus dimiliki adalah kemampuan berpikir kreatif dan kritis.

Selain itu, matematika juga merupakan suatu pembelajaran yang banyak melibatkan siswa ke dalam pemecahan masalah. Namun, untuk masuk pada tahap penyelesaian pemecahan masalah, siswa harus memahami soal dan membuat model matematika terlebih dahulu. Dari tahap ini lah yang sebenarnya telah menuntut siswa untuk berpikir kreatif. Seperti yang dikemukakan oleh (Meika \& Sujana, 2017) bahwa dalam menyelesaikan suatu masalah peserta didik memerlukan kemampuan berpikir kreatif. Adapun contoh dari kemampuan berpikir kreatif adalah kemampuan berpikir divergen, kemampuan untuk menemukan gagasan baru, dan kemampuan untuk mengkombinasikan gagasan.

Kemampuan berpikir kreatif adalah kemampuan untuk menyelesaikan masalah dengan solusi yang bervariasi dan tidak biasa digunakan oleh kebanyakan orang pada 
umumnya. Hal ini senada dengan pendapat (Marliani, 2015) yang menyatakan bahwa kemampuan berpikir kreatif merupakan kemampuan untuk mengembangkan atau menghasilkan ide-ide baru dan memiliki hasil pemikiran yang berbeda. Dengan berpikir kreatif, siswa akan memiliki kepekaan terhadap masalah, lalu mengidentifikasikan masalah, sampai pada akhirnya ia mampu menemukan ide-ide yang akan menyelesaikan masalah tersebut. (Sumarmo, 2014) juga mengemukakan bahwa pemecahan masalah memerlukan ide-ide baru yang berasal dari kreativitas individu. Dari sini lah dapat dikatakan bahwa kemampuan berpikir kreatif merupakan salah satu hal penting yang harus dimiliki oleh peserta didik dalam mempelajari ilmu matematika.

Dalam bidang ilmu matematika, kemampuan berpikir kreatif dapat disebut sebagai kemampuan berpikir kreatif matematis. (Marliani, 2015) menyebutkan bahwa kemampuan berpikir kreatif matematis adalah kemampuan dalam menyelesaikan permasalahan matematika melalui banyak penyelesaian dan memiliki sikap keluwesan dan kelancaran dalam berpikir, mampu melakukan elaborasi, serta mempunyai jawaban yang orisinil. Maka, ketika siswa mampu menyelesaikan suatu persoalan yang diberikan, ia akan mulai berpikir dengan tekun dan cermat sehingga hasil dari buah pemikirannya itu sendiri yang akan menghasilkan jawaban-jawaban bervariasi. Kondisi siswa seperti ini lah yang dapat dikatakan sebagai siswa yang memiliki kemampuan berpikir kreatif. Selanjutnya, siswa yang memiliki kemampuan berpikir kreatif akan menyelesaikan permasalahan matematika dengan cara yang inovatif. Hal ini dikarenakan ia mampu melihat permasalahan dari sudut pandang yang berbeda. (Putri, Munzir, \& Abidin, 2019) berpendapat bahwa proses berpikir kreatif membuat siswa melihat suatu permasalahan dari sudut pandang berbeda sehingga ia mampu memperoleh jawaban dengan berbagai cara. Oleh karena itu, siswa yang kreatif dapat dengan mudah menyelesaikan suatu persoalan sehingga dapat memperoleh hasil belajar yang baik. Sebaliknya, siswa yang memiliki kemampuan kreatifitas rendah akan memperoleh hasil belajar yang rendah pula. (Sari et al., 2019) menyatakan bahwa tingkat kreativitas siswa yang rendah akan memberikan dampak pada rendahnya hasil belajar siswa, hal ini dapat disebabkan oleh kurangnya pembiasan dalam memberikan soal-soal yang berhubungan dengan kehidupan sehari-hari yang bertujuan untuk melatih pemahaman siswa atas suatu konsep melalui pengalaman langsung. Oleh karena itu, untuk mengasah kemampuan berpikir kreatif matematis siswa demi memperoleh hasil belajar yang ideal maka siswa membutuhkan 
pembiasaan mengerjakan soal-soal yang materinya dapat dikaitkan dengan kehidupan sehari-hari. Salah satu materi matematika yang dapat dikaitkan dengan kehidupan seharihari adalah Sistem Persamaan Linier Dua Variabel (SPLDV). Dalam materi tersebut terdapat beberapa pembahasan yang dapat mengajak siswa untuk membayangkan suatu permasalahan yang diberikan. Salah satu contohnya adalah sebagai berikut:

Farah mengeluarkan uang Rp. 30.000 untuk membeli 5 buku tulis dan 2 lusin pensil. Sedangkan Eca mengeluarkan uang sebanyak Rp. 36.000 untuk membeli

3 buku tulis dan 3 lusin pensil. Berapa harga 3 buku tulis dan 7 lusin pensil?

Dari soal tersebut terlihat bahwa unsur-unsur yang diketahui serta contoh objek yang digunakan bukanlah sesuatu yang asing bagi siswa, melainkan hal-hal yang sering mereka jumpai. Dengan begitu, siswa dapat dengan mudah memahami persoalan yang diberikan dan diharapkan mampu menyelesaikannya dengan menggunakan cara mereka sendiri. Selanjutnya, berdasarkan buku yang dikeluarkan Kementrian Pendidikan dan Kebudayaan Republik Indonesia (Kemendikbud) edisi revisi 2017, materi SPLDV hanya terdapat di kelas VIII. Oleh karena itu, peneliti melakukan observasi untuk mengetahui kemampuan berpikir kreatif matematis pada siswa kelas VIII MTs Al-Kamil, Jatiuwung.

Namun, berdasarkan hasil observasi di kelas tersebut, ternyata kemampuan berpikir kreatif masih tergolong rendah setelah diberikannya soal pada materi SPLDV. Hal ini terlihat pada penyelesaian yang dikerjakan oleh siswa. Berikut adalah salah satu contoh penyelesaiannya:

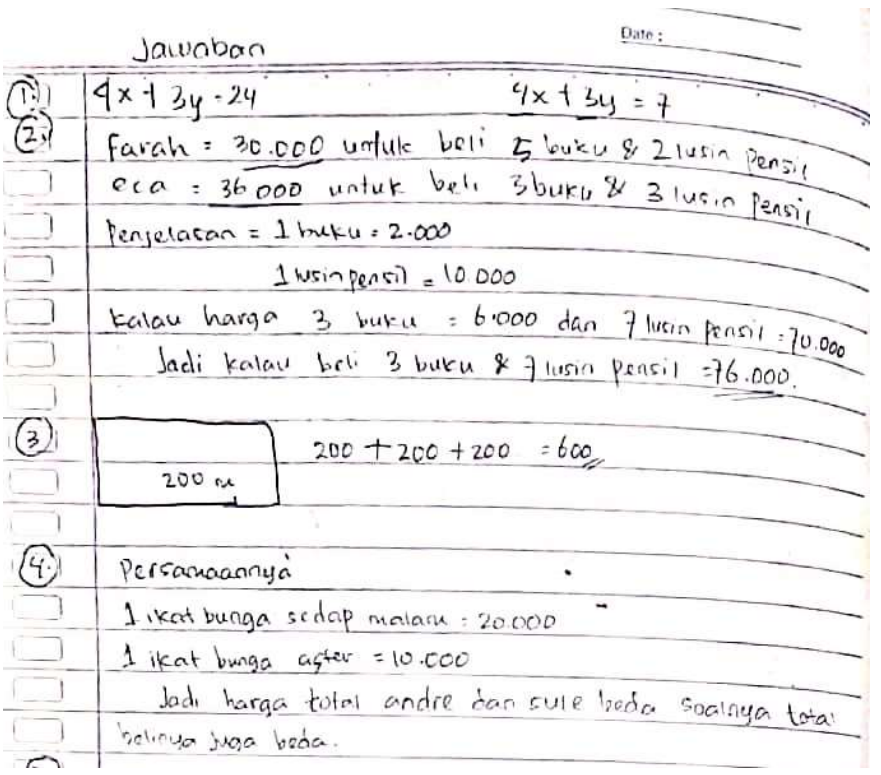

Gambar 1 jawaban sampel nomor 034 
Dari gambar di atas, terlihat bahwa peserta didik memberikan penyelesaian dengan menggunakan cara yang tidak bervariasi bahkan cenderung kurang relevan terhadap pertanyaan yang diajukan. Selain contoh di atas, terdapat pula banyak peserta didik lainnya yang menjawab dengan menggunakan cara yang hampir sama. Hal ini menunjukan bahwa sebagian besar peserta didik di kelas tersebut memiliki kemampuan yang kurang dalam menciptakan gagasan baru dan berbeda dari orang lain. Oleh sebab itu, dapat dikatakan bahwa kemampuan berpikir kreatif matematis pun juga cenderung rendah. Mengingat bahwa definisi berpikir kreatif adalah suatu pemikiran yang berusaha menciptakan gagasan baru (Huda, 2011). Berdasarkan observasi yang dilakukan peneliti di Mts.Al-Kamil, peneliti menyimpulkan bahwa salah satu faktor penyebab rendahnya kemampuan berpikir kreatif matematis siswa di pengaruhi oleh proses pembelajaran yang konvensional, yaitu siswa hanya dituntut untuk menghapal dan menggunakan rumus yang telah diberikan oleh guru.

Melihat permasalahan yang ada, maka diperlukan suatu model pembelajaran baru yang diharapkan mampu meningkatkan kemampuan berpikir kreatif siswa. Dalam penelitian sejenis, Pembelajaran Matematika Realistik (PMR) adalah model pembelajaran yang mampu memuat kreativitas seorang siswa seperti melakukan aktivitas-aktivitas eksplorasi, penemuan, pemecahan masalah, dan mengikuti pikiran orang lain (Muhtadi \& Sukirwan, 2018). Adapun kajian singkat mengenai penelitianpenelitian sejenis yang pernah dilakukan sebelumnya tertuang dalam tabel berikut:

Tabel 1 State of The Art

\begin{tabular}{|c|c|c|}
\hline No & Deskripsi Jurnal & Pembahasan \\
\hline \multirow[t]{10}{*}{1.} & Judul : & Hasil Penelitian : \\
\hline & Analisis Kemampuan Berpikir Kreatif & Terdapat perbedaan kemampuan siswa \\
\hline & Matematis Siswa Kelas VIII SMP & dalam menyelesaikan \\
\hline & pada Sistem Persamaan Linear Dua & kemampuan berpikir kreatif pada \\
\hline & Variabel (SPLDV). & indikator yang telah ditentukan. \\
\hline & Tahun : 2018 & \\
\hline & Peneliti : & Alasan Menjadi Tinjauan Penelitian : \\
\hline & Mayasari, $\quad$ Siska Ratnaputri, & Jurnal ini dapat memperkuat penelitian \\
\hline & Nursafitri, Novia Handayani, Wahyu & dengan memberikan referensi mengenai \\
\hline & Hidayat & seberapa signifikan pengaruh berpikir \\
\hline
\end{tabular}




\begin{tabular}{|c|c|c|}
\hline No & Deskripsi Jurnal & Pembahasan \\
\hline & Metode Penelitian : Kualitatif- & kreatif, khususnya pada mata pelajaran \\
\hline & Deskriptif & Sistem Persamaan Linear Dua Variabel \\
\hline & Penerbit Jurnal : Pendidikan Tambusi & (SPLDV). \\
\hline \multirow[t]{13}{*}{2.} & Judul : & Hasil Penelitian : \\
\hline & Peningkatan Kemampuan Berpikir & Peningkatan kemampuan berpikir kreatif \\
\hline & Kreatif dan Pemecahan Masalah & dan pemecahan masalah siswa dengan \\
\hline & Matematis Melalui Pendekatan & pembelajaran matematika realistik lebih \\
\hline & Matematika Realistik. & baik dari siswa yang mendapatkan \\
\hline & Tahun : 2016 & pembelajaran konvensional. \\
\hline & Peneliti : Iwa Kartiwa & \\
\hline & Metode Penelitian : & Alasan Menjadi Tinjauan Penelitian : \\
\hline & Mix Method ragam embedded & Dapat dijadikan sebagai rujukan bahwa \\
\hline & Penerbit Jurnal : & pembelajaran matematika realistik lebih \\
\hline & Universitas Pasundan: institutional & baik dari pembelajaran konvensional, \\
\hline & repositories \& scientific journals. & khususnya pada kemampuan berpikir \\
\hline & & kreatif. \\
\hline \multirow[t]{14}{*}{3.} & Judul : & Hasil Penelitian : \\
\hline & Upaya Meningkatkan Kemampuan & Kemampuan berpikir kreatif siswa \\
\hline & Berpikir Kreatif Siswa SMP dengan & dengan menggunakan Pendekatan \\
\hline & Pendekatan Matematika Realistik & Matematika Realistik Indonesia lebih \\
\hline & Indonesia & baik daripada kemampuan berpikir \\
\hline & Tahun : 2015 & kreatif siswa yang menggunakan \\
\hline & Peneliti : & pembelajaran konvensional. \\
\hline & Joni Iskandar dan Reni Riyanti & \\
\hline & Metode Penelitian : & Alasan Menjadi Tinjauan Penelitian : \\
\hline & Kuasi eksperimen dengan desain & Dapat dijadikan bahan tambahan untuk \\
\hline & kelompok kontrol pretes dan postes & memperkuat penelitian yang sedang \\
\hline & Penerbit Jurnal : & dibuat oleh peneliti agar mendapat hasil \\
\hline & Seminar Nasional Matematika dan & akhir yang signifikan. \\
\hline & Pendidikan Matematika UNY & \\
\hline
\end{tabular}


Dari tabel 2 dapat dilihat bahwa judul penelitian sebelumnya hampir sama dengan judul penelitian yang dilakukan oleh peneliti. Pada jurnal 1, (Mayasari, Ratnapuri, Nursafitri, Handayani, \& Hidayat, 2018) menggunakan metode penelitian KualitatifDeskriptif dan penelitian tersebut mengarah pada analisis kemampuan berpikir kreatif. Sedangkan yang membedakan penelitian tersebut dengan penelitian yang dilakukan oleh peneliti adalah peneliti menggunakan metode penelitian kuantitatif dan penelitian ini mengarah pada peningkatan kemampuan berpikir kreatif. Lalu, pada jurnal 2 yang dilakukan oleh (Kartiwa, 2016) terdapat kesamaan terhadap tujuan penelitian, yaitu untuk mengetahui peningkatan kemampuan berpikir kreatif. Namun, metode penelitian yang dilakukan berbeda dengan yang dilakukan oleh peneliti. Jurnal tersebut menggunakan metode penelitian mix method. Terakhir, (Iskandar, 2015) telah melakukan penelitian yang hampir mirip dengan penelitian yang dilakukan oleh peneliti. Hanya saja, penelitian tersebut menggunakan variabel PMRI, sedangkan penelitian ini menggunakan variabel PMR. Meskipun PMR dan PMRI terlihat sama, akan tetapi kedua pembelajaran tersebut nyatanya berbeda. (Saefudin, 2012) mengatakan bahwa meskipun PMRI merupakan adaptasi dari PMR tetapi terdapat beberapa perbedaan dikarenakan konteks budaya, sistem sosial, dan alamnya. Meskipun terdapat beberapa perbedaan, penelitian-penelitian tersebut mempunyai dasar penelitian yang sama, yaitu menganggap bahwa pembelajaran matematika realistik merupakan pembelajaran yang dapat memberikan pengaruh pada kemampuan berpikir kreatif siswa. (Usdiyana, Purniati, Yulianti, \& Harningsih, 2009) pun juga memaparkan bahwa dengan melakukan pembelajaran matematika realistik, siswa dapat berkontribusi dalam membangun pengetahuan mereka menggunakan caracara informal sampai formal dari bentuk soal yang mengarah pada jawaban divergen. Pemaparan tersebut sejalan dengan kriteria berpikir kreatif yaitu siswa dapat bereksplorasi sendiri untuk dapat mencari berbagai jawaban. Dengan PMR, siswa diharuskan untuk menyelesaikan masalah matematika yang dapat dibayangkan oleh akal pikirannya, salah satu contohnya ialah masalah yang berkaitan dengan kehidupan seharihari. Selain itu, dengan memberikan permasalahan yang realistik, siswa akan mampu menemukan kembali konsep baru berdasarkan hasil eksplorasinya sendiri.

Berdasarkan uraian di atas maka masalah yang diteliti adalah, "Apakah terdapat peningkatan kemampuan berpikir kreatif matematis siswa SMP melalui pembelajaran matematika realistik pada materi sistem persamaan linier dua variabel?" 
Adapun tujuan penelitian ini adalah, "Untuk mengetahui apakah terdapat peningkatan kemampuan berpikir kreatif matematis siswa SMP melalui pembelajaran matematika realistik pada materi sistem persamaan linier dua variabel.”

\section{METODOLOGI}

Penelitian ini menggunakan pendekatan kuantitatif dengan jenis penelitiannya adalah metode penelitian eksperimen. Dalam pelaksanaanya, peneliti menggunakan kelompok kelas eksperimen dan kelompok kelas kontrol dimana kedua kelompok kelas tersebut diberikan soal pretes dan soal postes. Pada kelompok kelas eksperimen akan diberikan perlakuan yaitu melaksanakan pembelajaran menggunakan pendekatan PMR. Sementara pada kelas kontrol akan diberikan pembelajaran menggunakan model pembelajaran konvensional.

Populasi dalam penelitian ini adalah seluruh peserta didik kelas VIII MTs Al-Kamil, Jatiuwung, Kota Tangerang. Lalu, sampel yang terpilih adalah kelas VIII A dengan yang menjadi kelas eksperimen dan kelas VIII B d yang menjadi kelas kontrol dengan masingmasing siswanya berjumlah 21 siswa. Adapun teknik pengambilan sampel dilakukan dengan menggunakan teknik simple random samping.

Dalam pembelajaran yang dilakukan pada penelitian ini, materi yang digunakan adalah Sistem Persamaan Linier Dua Variabel (SPLDV) dengan instrumen penelitian soal pretes dan soal postes. Instrumen penelitian berbentuk essay berisi 4 soal dan telah di validasi oleh guru pengajar bidang ilmu matematika dengan presentase skor adalah $87,55 \%$ artinya termasuk kriteria valid dan tidak perlu revisi. Lalu, teknik analisis data yang digunakan adalah uji normalitas Saphiro-Wilk karena sampel dalam ruang lingkup kecil, kemudian uji homogenitas untuk mengetahui data berasal dari varian yang sama atau tidak, dan uji Normalized Gain (N-Gain) untuk mengetahui peningkatan kemapuan berpikir kreatif matematis.

\section{HASIL DAN PEMBAHASAN}

Untuk mengetahui peningkatan kemampuan berpikir kreatif melalui pembelajaran matematika realistik maka akan dilakukan uji Normalized gain ( $\mathrm{N}$-gain). Namun, sebelum melakukan uji Gain, terlebih dahulu melakukan pengujian normalitas dan homogenitas 
sebaran data. Penelitian ini menggunakan software SPSS versi 22 dalam menganalisis data yang telah terkumpul.

Dalam melakukan pengujian data berdistribusi normal, maka peneliti menggunakan uji normalitas Saphiro-Wilk dikarenakan jumlah sampel < 50. Berdasarkan output SPSS data nilai pretes kedua kelas berdistribusi normal. Hal ini ditunjukan oleh tabel berikut:

Tabel 2 uji normalitas data nilai pretes

\begin{tabular}{|c|c|c|c|c|c|c|}
\hline & \multicolumn{3}{|c|}{ Kolmogorov-Smirnov ${ }^{a}$} & \multicolumn{3}{|c|}{ Shapiro-Wilk } \\
\hline & Statistic & df & Sig. & Statistic & df & Sig. \\
\hline pretes_eksperimen & 174 & 21 & ,097 & 911 & 21 & ,058 \\
\hline pretes_kontrol & ,252 & 21 & ,001 & ,909 & 21 &, 053 \\
\hline
\end{tabular}

Berdasarkan Tabel.2. terlihat bahwa nilai Sig. Pretes pada kelas eksperimen adalah 0,058 dan nilai Sig. Postes pada kelas kontrol adalah 0,053. Kedua nilai tersebut bernilai $>0,05$ ini berarti bahwa kedua data nilai pretes pada kelas eksperimen dan kelas kontrol berdistribusi normal.

Kemudian pada data nilai postes kelas eksperimen dan kelas kontrol pun juga berdistribusi normal. Hal ini terlihat pada Tabel.3.

Tabel 3 uji normalitas data nilai postes

\begin{tabular}{|c|c|c|c|c|c|c|}
\hline & \multicolumn{3}{|c|}{ Kolmogorov-Smirnova } & \multicolumn{3}{|c|}{ Shapiro-Wilk } \\
\hline & Statistic & Df & Sig. & Statistic & df & Sig. \\
\hline postes_eksperimen & ,171 & 21 & ,110 & ,942 & 21 & ,241 \\
\hline postes_kontrol & ,134 & 21 &, $200^{*}$ & ,961 & 21 &, 543 \\
\hline
\end{tabular}

Pada nilai Sig. Postes kelas eksperimen menunjukan 0,241 dan kelas kontrol 0,543. Kedua nilai signifikan memenuhi syarat data yang berdistribusi normal, yaitu lebih dari 0,05 .

Setelah menghitung normalitas suatu data, maka data nilai pretes dan nilai postes kembali dihitung menggunakan SPSS untuk dilakukan pengujian homogenitas. Uji homogenitas adalah pengujian mengenai sama tidaknya variasi-variasi dua buah distribusi atau lebih. Pada data nilai pretes kelas eksperimen dan kelas kontrol data bersifat homogen. Hal ini dibuktikan oleh tabel output SPSS yang bernilai signifikan $>0,05$. Berikut adalah tabelnya: 
Tabel 4 uji homogenitas data pretes

\begin{tabular}{llrrrr}
\hline \multirow{2}{*}{ pretes } & Levene Statistic & df1 & df2 & Sig. \\
\cline { 2 - 6 } & Based on Mean & 3,842 & 1 & 40 &, 057 \\
& Based on Median & 3,592 & 1 & 40 &, 065 \\
Based on Median and with & 3,592 & 1 & 36,016 &, 066 \\
adjusted df & & & & \\
Based on trimmed mean & 3,941 & 1 & 40 &, 054 \\
\hline
\end{tabular}

Selanjutnya, pada data nilai postes kelas eksperimen dan kontrol pun juga bersifat homogen. Hal ini terlihat pada nilai signifikan yang lebih dari 0,05 . Berikut adalah tabelnya:

Tabel 5 uji homogenitas data postes

\begin{tabular}{llrrrr}
\hline \multirow{2}{*}{ postes } & & Levene Statistic & df1 & df2 & Sig. \\
\cline { 2 - 5 } & Based on Mean & 1,066 & 1 & 40 &, 308 \\
& Based on Median & 1,063 & 1 & 40 &, 309 \\
Based on Median and with & 1,063 & 1 & 38,449 &, 309 \\
adjusted df & & & & \\
Based on trimmed mean & 1,109 & 1 & 40 &, 299 \\
\hline
\end{tabular}

Langkah selanjutnya adalah mencari apakah terdapat peningkatan kemampuan berpikir kreatif matematis melalui pembelajaran matematika realistik, yaitu dengan melakukan uji normalized gain (uji N-Gain). Adapun rumus uji N-Gain adalah sebagai berikut:

$$
N \text { Gain }=\frac{\text { skor posttest }- \text { skor pretest }}{\text { skor ideal }- \text { skor pretest }}
$$

Dengan bantuan software SPSS maka di dapat rata-rata nilai N-Gain score untuk kelas eksperimen adalah sebesar 0,28 atau sekitar 28\%. Sedangkan rata-rata nilai N-Gain score untuk kelas kontrol adalah sebesar 0,03 atau sekitar 3\%. Berdasarkan kategori perolehan N-Gain dalam bentuk persen, maka pembelajaran matematika realistik tidak efektif untuk meningkatkan kemampuan berpikir kreatif matematis siswa. berikut adalah tabel kategorisasi score N-Gain:

Tabel 6 kategori score N-Gain dalam persen

\begin{tabular}{cc}
\hline Persentase & Tafsiran \\
\hline$<40$ & Tidak Efektif \\
$40-55$ & Kurang Efektif \\
$56-75$ & Cukup Efektif \\
$>76$ & Efektif \\
\hline
\end{tabular}


Adapun kategori yang ditinjau dari tabel N-Gain score sebagai berikut:

\section{Tabel 7 interpretasi skor rata-rata N-Gain}

\begin{tabular}{ccc}
\hline Nilai $\mathrm{g}$ & Kriteria & \\
\hline $\mathrm{g} \geq 0,7$ & Tinggi & \\
$0,3 \leq \mathrm{g}<0,7$ & Sedang & \\
$\mathrm{g}<0,3$ & Rendah & \\
\hline & & $($ Hake, 1999)
\end{tabular}

Pada tabel 6 terlihat bahwa peningkatan kemampuan berpikir kreatif melalui pendekatan PMR pada kelas eksperimen maupun kelas kontrol tergolong kriteria rendah, yaitu dengan peningkatan sebesar 0,28 pada kelas eksperimen dan 0,03 pada kelas kontrol. Dengan begitu, dapat disimpulkan bahwa pembelajaran yang dilaksakan melalui PMR dinilai tidak efektif sehingga untuk meningkatan kemampuan berpikir kreatif tergolong rendah.

Berdasarkan pengujian yang telah dilakukan menggunakan uji N-Gain, terlihat bahwa skor N-Gain pada kedua kelas berada pada persentase $<40$, sehingga berada pada kategori "Tidak Efektif". Akan tetapi, pada rata-rata skor pretes dan postes pada kedua kelompok kelas mengalami peningkatan. Pada kelas eksperimen rata-rata skor pretes adalah 47,8 dan rata-rata skor postes adalah 64,7. Sedangkan, pada kelas kontrol rata-rata skor pretes adalah 42,3 dan rata-rata skor postes adalah 44,2. Meski begitu, tetap saja apabila pembelajaran yang dilakukan tidak efektif maka peningkatannya pun akan rendah.

Berdasarkan hasil penelitian yang telah diuraikan, peningkatan kemampuan berpikir kreatif matematis siswa yang mendapatkan pembelajaran matematika realistik lebih baik dari pada siswa yang mendapatkan pembelajaran konvensional. Hal ini dibuktikan dengan adanya nilai rata-rata kelas eksperimen yang lebih besar dibandingkan kelas kontrol yang dilakukan melalui instrumen tes berdasarkan indikator kemampuan berpikir kreatif matematis. Meskipun pembelajaran matematika realistik mampu meningkatkan kemampuan berpikir kreatif, akan tetapi hasil penelitian menunjukan bahwa pembelajaran tersebut tidak efektif. Hal ini tentu saja dapat terjadi karena beberapa faktor. Pada saat penelitian, proses pembelajaran hanya berlangsung satu jam. Hal ini yang diduga membuat kegiatan pembelajaran yang dilakukan menjadi kurang maksimal karena keterbatasan waktu. Pada saat proses pembelajaran menggunakan PMR, siswa menjadi lebih aktif dalam belajar karena materi yang disampaikan telah dikaitkan dengan kehidupan sehari-hari dan dengan bahasa yang mudah dipahami sehingga terjadi interaksi 
dua arah antara pengajar dengan siswa. Selain itu, proses pembelajaran yang di laksanakan dapat membuka pola pikir siswa yang membuat siswa ikut berpartisipasi dalam berpikir untuk menemukan jawaban. Hal ini terlihat pada saat peneliti memberikan sebuah pertanyaan secara lisan yang berkaitan dengan materi pembelajaran kemudian sebagian besar siswa mencoba menjawab pertanyaan dari hasil pemikirannya. Meskipun begitu, proses pembelajaran dengan metode PMR memerlukan lebih banyak waktu dibandingkan pembelajaran dengan metode konvensional.

Berdasarkan penelitian yang telah di lakukan oleh Mayasari, Ratnapuri, Nursafitri, Handayani, \& Hidayat (2018), setiap siswa memiliki kemampuan berpikir kreatif yang berbeda-beda sesuai dengan indikatornya. Hal ini dapat dilihat dari presentase setiap butir soal yang dibuat berdasarkan kemampuan berpikir kreatif. Penelitian tersebut sejalan dengan penelitian yang telah dilakukan oleh peneliti. Pada penelitian ini, tiap siswa mampu menjawab dengan masing-masing soal yang berbeda-beda. Hal ini membuktikan bahwa kemampuan berpikir kreatif yang dimiliki oleh siswa pun berbeda.

Selanjutnya, Kartiwa (2016) dalam penelitiannya menyimpulkan bahwa peningkatan kemampuan berpikir kreatif dan pemecahan masalah pada pembelajaran matematika realistik lebih baik dari pembelajaran konvensional. Penelitian ini memiliki kesesuaian dengan penelitian yang telah dilakukan oleh peneliti. Pada penelitian ini, pembelajaran matematika realistik lebih baik dibandingkan pembelajaran konvensional sebagai upaya peningkatan kemampuan berpikir kreatif matematis. Akan tetapi, peningkatan yang diperoleh kurang signifikan sehingga masuk dalam kategori "Tidak Efektif”.

Selain itu, terdapat pula hasil penelitian yang telah dilakukan oleh Iskandar (2015). Dalam penelitiannya, Iskandar menggunakan pendekatan PMRI. Hasil yang diperoleh dari penelitian tersebut adalah bahwa peningkatan kemampuan berpikir kreatif menggunakan pendekatan PMRI lebih baik dibandingkan pembelajaran konvensional. Hal ini sesuai dengan hasil penelitian yang dilakukan oeh peneliti. Meskipun begitu, terdapat perbedaan dalam penarikan kesimpulan antara penelitian yang dilakukan oleh Iskandar dengan penelitian yang dilakukan oleh peneliti. Kesimpulan yang dilakukan oleh peneliti menggunakan "kategori” peningkatan, sedangkan Iskandar menarik kesimpulan dengan membandingkan pembelajaran PMRI dengan konvensional. Hal ini tentu dapat terjadi karena perbedaan rumus uji yang digunakan. 


\section{SIMPULAN}

Berdasarkan penelitian yang diperoleh, maka kesimpulan dari penelitian ini adalah penggunaan pendekatan PMR tidak efektif dalam meningkatkan kemampuan berpikir kreatif matematis siswa sehingga mengalami peningkatan yang rendah. Hal ini tentunya dapat terjadi karena beberapa faktor. Salah satu faktornya adalah kurangnya kegiatan pembelajaran secara maksimal. Namun, berdasarkan teori yang ada pendekatan PMR seharusnya mampu untuk meningkatan kemampuan berpikir kreatif mengingat bahwa PMR merupakan salah satu cara untuk mengasah kemampuan anak dalam bereksplorasi sehingga memunculkan gagasan baru dimana hal tersebut merupakan salah satu definisi dari kemampuan berpikir kreatif.

Kepada peneliti yang berminat melakukan penelitian dengan variabel yang sama dengan penelitian ini, disarankan untuk melaksanakan proses pembelajaran dengan waktu yang relatif lebih lama sehingga proses pembelajaran dapat dilaksanakan dengan maksimal. Selain itu, kepada peneliti selanjutnya diharapkan melakukan penelitian menggunakan materi yang berbeda agar pengajar mengetahui bahwa ada pula materi lain yang mampu menjadi bahan dalam pembelajaran matematika realistik sebagai upaya dalam meningkatkan kemampuan berpikir kreatif matematis.

\section{DAFTAR PUSTAKA}

Hake, R. R. (1999). Analyzing change/gain scores. Unpublished.[Online] URL: Http://Www. Physics. Indiana. Edu/ Sdi/AnalyzingChange-Gain. Pdf.

Handoko, H. (2017). Pembelajaran Matematika Model Savi Berbasis Discovery Strategy Materi Dimensi Tiga Kelas X . EduMa.

Huda, C. (2011). Meningkatkan kemampuan berpikir kreatif siswa dalam memecahkan masalah Matematika dengan model Pembelajaran Treffinger pada materi pokok Keliling dan Luas Persegi dan Persegipanjang. Digital Library: UIN Sunan Ampel.

Iskandar, J. (2015). Upaya Meningkatkan Kemampuan Berpikir Kreatif Siswa SMP Dengan Pendekatan Matematika Realistik Indonesia. Seminar Nasional Matematika Dan Pendidikan Matematika UNY.

Kartiwa, I. (2016). Peningkatan Kemampuan Berpikir Kreatif dan Pemecahan Masalah Matematis Melalui Pendekatan Matematika Realistik. Universitas Pasundan: Institutional repositories \& scientific journals. 
Marliani, N. (2015). Peningkatan Kemampuan Berpikir Kreatif Matematis Siswa melalui Model Pembelajaran Missouri Mathematics Project (MMP). Formatif: Jurnal Ilmiah Pendidikan MIPA.

Mayasari, M., Ratnapuri, S., Nursafitri, N., Handayani, N., \& Hidayat, W. (2018). Analisis Kemampuan Berpikir Kreatif Matematis Siswa Kelas VIII SMP pada Sistem Persamaan Linear Dua Variabel (SPLDV). Jurnal Pendidikan Tambusai.

Meika, I., \& Sujana, A. (2017). Kemampuan Berpikir Kreatif dan Pemecahan Masalah Matematis Siswa SMA. Jurnal Penelitian Dan Pembelajaran Matematika.

Muhtadi, D., \& Sukirwan, S. (2018). Implementasi Pendidikan Matematika Realistik (PMR) untuk Meningkatkan Kemampuan Berpikir Kreatif Matematik dan Kemandirian Belajar Peserta Didik. Mosharafa: Jurnal Pendidikan Matematika.

Putri, C. A., Munzir, S., \& Abidin, Z. (2019). Kemampuan Berpikir Kreatif Matematis Siswa melalui Model Pembelajaran Brain-Based Learning. Jurnal Didaktik Matematika.

Saefudin, A. A. (2012). Pengembangan Kemampuan Berpikir Kreatif Siswa Dalam Pembelajaran Matematika Dengan Pendekatan PMRI. Al-Bidayah.

Sari, V. A., Studi, P., Matematika, P., Keguruan, F., Ilmu, D. A. N., \& Surakarta, U. M. (2019). Dampak Strategi Pembelajaran dan Tingkat Kreativitas Siswa Terhadap Hasil Belajar Matematikar Retrieved from http://eprints.ums.ac.id/71794/11/NASKAH PUBLIKASI-37.pdf

Sumarmo, U. (2014). Berpikir dan Disposisi Matematika Serta Pembelajarannya. Kumpulan Makalah Pendidikan Matematika FPMIPA UPI Bandung.

Usdiyana, D., Purniati, T., Yulianti, K., \& Harningsih, E. (2009). Meningkatkan Kemampuan Berpikir Logis Siswa SMP melalui Pembelajaran Matematika Realistik. Jurnal Pengajaran Matematika Dan Ilmu Pengetahuan Alam.

Wijaya, A. (2012). Pendidikan matematika realistik: suatu alternatif pendekatan pembelajaran matematika. Yogyakarta : Graha Ilmu. 